\title{
Base temperature for node emission and plastochron determination in tomato species and their hybrids
}

\author{
André Ricardo Zeist ${ }^{(1)}$, Juliano Tadeu Vilela de Resende ${ }^{(1)}$, Marcos Ventura Faria(1), \\ André Gabriel(1), Israel Felipe Lustosa da Silva ${ }^{(1)}$ and Renato Barros de Lima Filho(1)
}

\begin{abstract}
(1)Universidade Estadual do Centro-Oeste, Campus Cedeteg, Rua Simeão Camargo Varela de Sá, no 03, Vila Carli, CEP 85040-080 Guarapuava, PR, Brazil. E-mail: andre.zeist@bol.com.br, jresende@unicentro.br, mfaria@unicentro.br, andre.gb85@hotmail.com, israel.felipe30@gmail.com, delimafilho.renato@yahoo.com
\end{abstract}

\begin{abstract}
The objective of this work was to estimate the base temperature for node emission and plastochron determination in wild species of tomato, in the Redenção cultivar, and in their respective interspecific $\mathrm{F}_{1}$ hybrids. The wild accessions Solanum pimpinellifolium AF 26970, Solanum galapagense LA-1401, Solanum peruvianum AF 19684, Solanum habrochaites var. hirsutum PI-127826, Solanum habrochaites var. glabratum PI-134417, and Solanum pennellii LA-716; the cultivar Redenção (Solanum lycopersicum); and their respective interspecific hybrids were evaluated, on the transplanting dates 12/22/2015, 2/12/2016, and 4/6/2016. The base temperature was estimated using the least mean squared error of the linear regression between the number of nodes and the accumulated thermal sum. The plastochron for the main stem and the first three lateral stems was estimated using the base temperature. The base temperature for node emission and plastochron determination varied from 4.5 to $14.8^{\circ} \mathrm{C}$. The species $S$. habrochaites var. hirsutum accession PI-127826, S. habrochaites var. glabratum accession PI-134417, and their hybrids with the Redenção cultivar showed the lowest base temperatures and plastochron for the main stem, whereas the remaining wild species and interspecific hybrids had a base temperature near that of cultivated tomato. Wild species and interspecific hybrids of tomato show a great variation in base temperature for node emission and plastochron determination.
\end{abstract}

Index terms: Solanum lycopersicum, pre-breeding, thermal time, wild accessions.

\section{Temperatura-base para emissão de nós e determinação de plastocrono em espécies de tomateiro e seus híbridos}

Resumo - O objetivo deste trabalho foi estimar a temperatura-base para emissão de nós e determinação de plastocrono em espécies silvestres de tomateiro, na cultivar Redenção e em seus respectivos híbridos interespecíficos $F_{1}$. Avaliaram-se os acessos silvestres Solanum pimpinellifolium AF 26970, Solanum galapagense LA-1401, Solanum peruvianum AF 19684, Solanum habrochaites var. hirsutum PI-127826, Solanum habrochaites var. glabratum PI-134417 e Solanum pennellii LA-716; a cultivar Redenção (Solanum lycopersicum); e os seus respectivos híbridos interespecíficos, nas datas de transplantio 22/12/2015, 12/2/2016 e 6/4/2016. A temperatura-base foi estimada com o método do menor quadrado médio do erro da regressão linear entre o número de nós e a soma térmica acumulada. O plastocrono para a haste principal e as três primeiras hastes laterais foi estimado com uso da temperatura-base. A temperatura base para emissão de nós e determinação do plastocrono variou entre 4,5 e $14,8^{\circ} \mathrm{C}$. As espécies $S$. habrochaites var. hirsutum acesso PI127826, S. habrochaites var. glabratum acesso PI-134417 e os respectivos híbridos com a cultivar Redenção apresentaram os menores valores de temperatura-base e plastocrono da haste principal, enquanto as demais espécies silvestres e os híbridos interespecíficos tiveram temperatura-base próxima à do tomateiro cultivado. As espécies silvestres e os híbridos interespecíficos de tomate mostram grande variação na temperatura-base para emissão de nós e determinação do plastocrono.

Termos para indexação: Solanum lycopersicum, pré-melhoramento genético, soma térmica, acessos silvestres.

\section{Introduction}

The cultivated tomato (Solanum lycopersicum L.) has 16 species, besides the cerasiforme variety, which show higher or lower interspecific cross-compatibility
(Peralta et al., 2008). Each species has specific minimum, maximum, optimum development, and growth temperatures. For grown tomatoes, the lower, upper, and optimal base temperatures for the emission of vegetative structures are, respectively, 10, 34, and 
$22^{\circ} \mathrm{C}$ (Pivetta et al., 2007). However, since there are no records of the cardinal temperatures for the growth and development of wild tomato species, there is a lack of basic information about the development of these species as a function of air temperature, which could facilitate the transfer of desirable characteristics and the selection of materials in breeding programs.

Since commercial tomato cultivars are susceptible to injury at temperatures close to or below $5^{\circ} \mathrm{C}$ (Easlon et al., 2013) and show limited production in regions of low air temperature (Venema et al., 2000, 2008), the variability wild in species should be assessed for tolerance to this type of stress. Unlike the cultivated tomato, wild species, especially Solanum habrochaites S.Knapp \& D.M.Spooner, are adapted to a wide range of latitudinal distribution and show favorable characteristics to plant development and growth even when thermal conditions are not so favorable during the day or along the cycle (Brüggemann \& Linger, 1994).

In general, the response of plants to environmental conditions is evaluated by the qualitative and quantitative description of their physiological behavior (Venema et al., 2008; Otto et al., 2013). However, the base air temperature limiting leaf or node emissions is commonly estimated by mathematical models. These models simulate plant development as a function of the required thermal sum and have been adopted, for example, by Martins et al. (2007) for seedlings of two species of eucalyptus (Eucalyptus saligna $\mathrm{Sm}$. and Eucalyptus grandis W.Hill), by Erpen et al. (2013) for sweet potato [Ipomoea batatas (L.) Lam.], by Lucas et al. (2012) for watermelon [Citrullus lanatus (Thunb.) Matsum. \& Nakai], by Callejas et al. (2014) for Roxa mango (Mangifera indica L.) cultivar, and by Müller et al. (2009) for ryegrass (Lolium multiflorum Lam.).

In addition to base temperature, the thermal sum is a measure used to observe the effect of temperature on vegetative development and growth, in ${ }^{\circ} \mathrm{C}$ day (Heldwein et al., 2010; Lucas et al., 2012). The thermal sum has a strong relationship with the emission of vegetative structures in tomatoes; therefore, the concept of plastochron $\left({ }^{\circ} \mathrm{C}\right.$ day by node), which is the period of time between the emergence of two successive nodes on the stem, allows estimating the number of nodes as a function of air temperature (Pivetta et al., 2007). Studies using the plastochron concept have been carried out for several agricultural species such as safflower (Carthamus tinctorius L.). by Streck et al. (2005), soybean [Glycine max (L.) Mer.] by Streck et al. (2008), cotton (Gossypium hirsutum L.) by Pereira et al. (2010), crambe (Crambe abyssinica Hochst.) by Toebe et al. (2010), snap beans (Phaseolus vulgaris L.) by Heldwein et al. (2010), watermelon by Lucas et al. (2010), sunflower (Helianthus annuus L.) by Souza et al. (2016), grapevine (Vitis vinifera L.) by Zeist et al. (2016, 2017), and even tomato by Pivetta et al. (2007). However, as is this case with base temperature, no studies using this concept are known for wild tomato species and interspecific hybrids.

Reliable base temperature and plastochron estimates allow identifying plant phenological behavior, defining management practices, assisting crop agricultural zoning, and identifying of genotypes best adapted to certain climatic conditions (Martins et al., 2007). Cultivars that require lower base temperatures for the emission of vegetative structures show lower susceptibility and greater efficiency, by increasing the production and adaptation of the tomato in sites where the temperatures are below $10^{\circ} \mathrm{C}$.

The objective of this work was to estimate the base temperature for node emission and plastochron determination in wild species of tomato, in the Redenção cultivar, and in their respective interspecific $\mathrm{F}_{1}$ hybrids.

\section{Materials and Methods}

The experiments were carried out in 2015 and 2016, at the plant research center of the Agronomy Department of Universidade Estadual do Centro-Oeste, located in the municipality of Guarapuava, in the state of Paraná, Brazil $\left(25^{\circ} 38^{\prime} \mathrm{S}, 51^{\circ} 48^{\prime} \mathrm{W}\right.$, at an altitude of $\left.1,100 \mathrm{~m}\right)$. The climate is of the humid mesothermal subtropical type according to Köppen's classification, with an irregular dry season, warm summer, and moderate winter (Wrege et al., 2011).

The experimental design was a randomized complete block with three replicates, and the treatments were distributed in a 13x3 factorial arrangment (genotypes $\mathrm{x}$ transplanting dates). The replicates consisted of three plants, with a spacing of 0.40 between pots. The genotypes evaluated were six wild accessions of tomato (Solanum pimpinellifolium accession AF 26970 , S. galapagense accession LA-1401, S. peruvianum accession AF 19684, S. habrochaites var. hirsutum 
accession PI-127826, S. habrochaites var. glabratum accession PI-134417, and S. pennellii accession LA716), the commercial cultivar Redenção (strain of $S$. lycopersicum with characteristics for processing), and their respective interspecific $\mathrm{F}_{1}$ hybrids, ('Redenção' x AF 26970, 'Redenção' x LA-1401, 'Redenção' x AF 19684, 'Redenção' x PI-127826, 'Redenção' x PI134417, and 'Redenção' x LA-716), obtained from the cross between 'Redenção' (female parent) and the wild accessions (male parents), on three transplanting dates: 12/22/2015, 2/12/2016, and 4/6/2016.

Sowing was performed in 200-cell expanded polystyrene trays containing commercial substrates based on bio-stabilized pine bark, maintained in a floating hydroponic system in a greenhouse. The AF 26970 and AF 19684 accessions, as well as the interspecific hybrids, were sown together with the Redenção cultivar. The LA-1401, PI-127826, PI134417, and LA-716 accessions were sown ten days earlier because the differences in their germination, emergence, and development. In order to guarantee a sufficient amount of seedlings, two seeds per cell were sown, with subsequent thinning of the seedlings between four and five days after emergence, leaving one seedling per cell.

Transplanting was performed when the seedlings had 4-5 leaves defined and expanded at 27, 25, and 26 days after emergence of the female parent on $12 / 22 / 2015$, 2/12/2016, and 6/4/2016, respectively. The seedlings were transplanted into pots with a capacity of $8 \mathrm{dm}^{3}$, which contained sieved soil and bovine manure in the proportion of 3:2. The soil was classified as an Oxisol of very clayey texture (Santos et al., 2013). The compound of sieved soil and bovine manure was previously corrected according to soil chemical analysis, by applying calcitic limestone, to raise base saturation $80 \%$ and to maintain the ratio of $4: 1$ between $\mathrm{Ca}$ and $\mathrm{Mg}$. For basic planting fertilization, $15 \mathrm{~g} \mathrm{~N}-\mathrm{P}_{2} \mathrm{O}_{5}-\mathrm{K}_{2} \mathrm{O}(04-20-20)$ and $7.0 \mathrm{~g}$ simple superphosphate were applied per pot.

Micro-drip irrigation was performed according to plant needs. The phytosanitary control was carried out according to the technical recommendations for the culture, with preventive sprayings of the commercial products: thiamethoxam (Actara), thiamethoxam + lambda-cyhalothrin (Engeo Pleno), copper oxychloride + mancozeb (Cuprozeb), and azoxystrobin + difenoconazole (Amistar Top).
During the experimental period, the daily data of minimum and maximum air temperatures were collected using maximum-minimum temperature thermometers. After the seedlings were transplanted, the number of nodes visible on the main stem and on the first three first-order lateral stems of each plant was counted weekly during the development and growth cycle. A new node was identified when it presented a leaf of at least $1 \mathrm{~cm}$ in length (Pivetta et al., 2007).

The daily thermal sum $\left(\mathrm{dTS},{ }^{\circ} \mathrm{C}\right.$ day) was calculated as proposed by Arnold (1960), dTS = (Tmean - Tbase) for 1 day; in which Tmean is the mean air temperature, calculated by the arithmetic mean between minimum and maximum air temperatures, and Tbase is the base temperature for node emission, below which there is no emission of new vegetative structures. The accumulated thermal sum (aTS, ${ }^{\circ} \mathrm{C}$ day) was defined by the sum of the daily values (aTS $=\sum \mathrm{dTS}$ ).

The number of nodes in the main stem was used to estimate Tbase, through the method of the least mean squared error (LMSE) of the linear regression between the number of nodes and the aTS (Sinclair et al., 2004; Martins et al., 2007; Lucas et al., 2012). According to these authors, Tbase values from 0 to $20^{\circ} \mathrm{C}$, with intervals of $0.5^{\circ} \mathrm{C}$, were tested in the mathematical model for the calculation of the dTS. The simple linear regression equations were estimated using the number of nodes in the main stem of each plot, and the aTS was calculated with the different Tbase. From the arithmetic mean of the plots, the LMSE was plotted as a function of Tbase. The Tbase value was obtained when the LMSE was observed.

For Tbase estimation, the number of nodes was counted from transplanting up to the beginning of fruit emergence on the stem, when at least $50 \%$ of the plants in the plot had at least one fruit at an early development stage. This period was chosen because, after the emergence of the first fruits, some tomato species and interspecific hybrids stopped the emission of nodes in the fruit stem.

The plastochron for the main stem and the first three lateral stems was estimated from Tbase, considering the same period of development and growth used to calculate Tbase. For this estimate, the inverse linear regression coefficient between the number of nodes visible on the stem and the aTS was used (Martins et al., 2007; Pivetta et al., 2007).

Pesq. agropec. bras., Brasília, v.53, n.3, p.307-315, Mar. 2018 DOI: 10.1590/S0100-204X2018000300005 
The plastochron data obtained from parents and interspecific hybrids were tested for normality and homogeneity of residual variances by the Lilliefors and Bartlett's tests, respectively. Subsequently, the data were subjected to the individual and joint analysis of variance by the F-test. When significant, means were subjected to the Scott-Knott grouping test, at 5\% probability, and analyzed by the statistical software Assistat, version 7.7 (Silva \& Azevedo, 2016).

\section{Results and Discussion}

The average air temperature was 23.8, 23.0, and $18.3^{\circ} \mathrm{C}$, and the absolute minimum and maximum temperatures were 14.1 and $33.9^{\circ} \mathrm{C}, 9.0$ and $32.6^{\circ} \mathrm{C}$, and 0.3 and $33.4^{\circ} \mathrm{C}$, respectively, for the transplanting dates 12/22/2015, 2/12/2016, and 4/6/2016 (Figure 1).

The regression equations between the number of nodes visible on the main stem and the aTS for the genotypes showed a close relationship $\left(R^{2} \geq 0.91\right)$, pointing to linearity. In addition, air temperature was considered the main meteorological element to control the emergence of vegetative structures, as also verified by Pivetta et al. (2007) in cultivated tomato, Martins et al. (2007) in eucalyptus, and Streck et al. (2005) in safflower. Likewise, Liu \& Heins (2002) stated the importance of thermal energy to plant growth and development due to the high linearity between the numbers of nodes and accumulated thermal sum of tomato species and interspecific hybrids.

A variation was observed for the LMSE of the regression equations for the Tbase values used to calculate the aTS of the genotypes on the three transplanting dates (Figure 2). The LMSE method was efficient in estimating the Tbase for all genotypes on all dates, except 12/22/2015 when the AF 26970 and LA-716 accessions and the 'Redenção' x AF 19684 hybrid presented decreasing LMSE with increasing Tbase.

In general, the estimated Tbase varied little among the three dates. The lowest Tbase values were verified for the wild species $S$. habrochaites var. hirsutum accession PI-127826 and S. habrochaites var. glabratum accession PI-134417, with values for the three dates ranging from $3.5^{\circ} \mathrm{C}(4 / 6 / 2016)$ to $6.5^{\circ} \mathrm{C}(12 / 22 / 2015)$ and from $3.5^{\circ} \mathrm{C}(4 / 6 / 2016)$ to $5.5^{\circ} \mathrm{C}$ $(12 / 22 / 2015)$, respectively (Figure 2$)$.
The lower Tbase for node emission observed for S. habrochaites var. hirsutum is in alignment with Patterson et al. (1978) and Venema et al. (2008), who found this variety is adaptable to a wide range of latitudinal distribution, with favorable physiological characteristics for plant growth and development, even at lower temperatures. However, there are no known reports on the vegetative development of $S$. habrochaites var. glabratum with lower thermal availability.

Low Tbase values were also verified for the 'Redenção' x PI-127826 and 'Redenção' x PI-134417 hybrids at the transplanting dates, ranging from $5.5^{\circ} \mathrm{C}(4 / 6 / 2016)$ to $7.0^{\circ} \mathrm{C}(2 / 12 / 2016)$ and from $5.5^{\circ} \mathrm{C}$
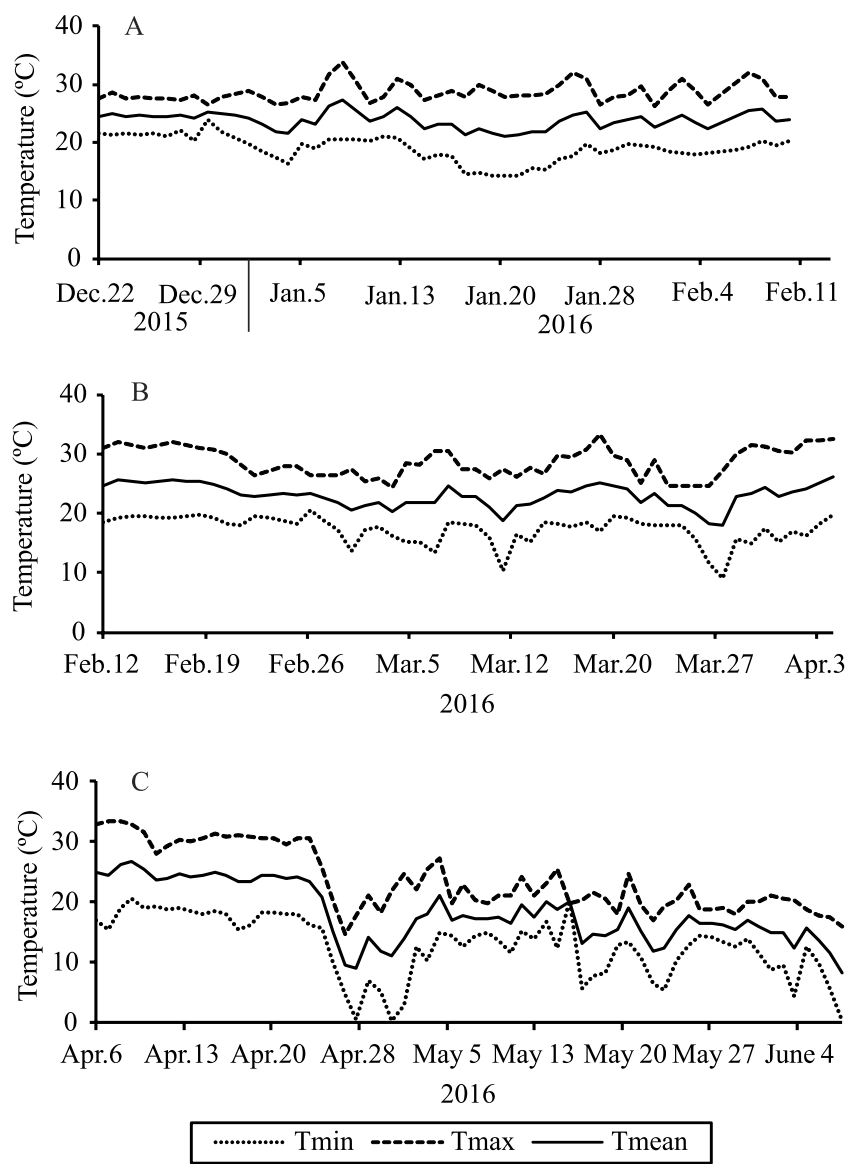

Figure 1. Minimum (Tmin), maximum (Tmax), and average (Tmean) air temperatures recorded during the monitoring of the Redenção cultivar (female parent), wild accessions (male parents), and respective interspecific hybrids of tomato (Solanum lycopersicum) on the transplanting dates 12/22/2015 (A), 2/12/2016 (B), and 4/6/2016 (C). 


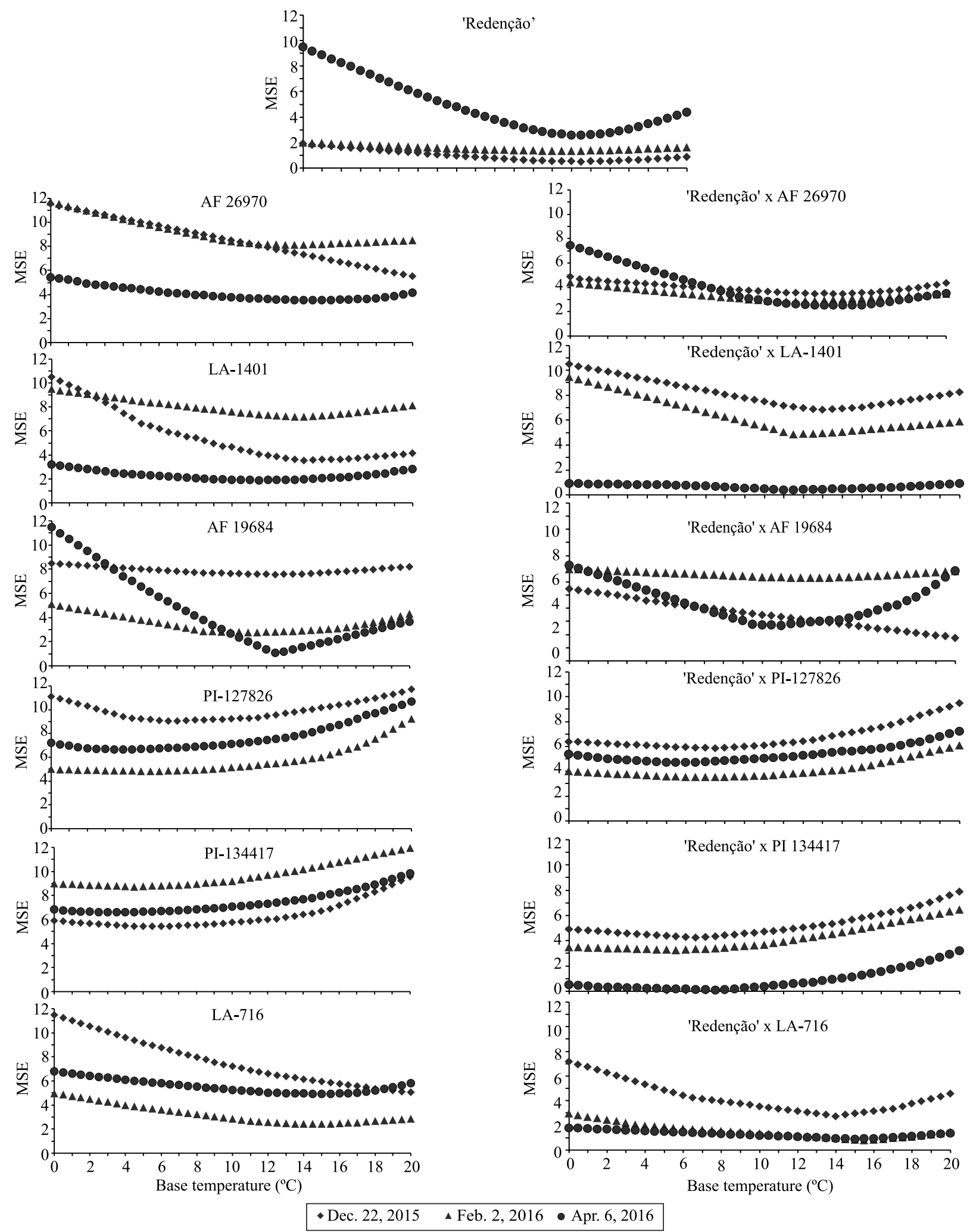

Figure 2. Mean squared error (MSE) of the linear regression between the number of nodes in the main stem and the accumulated thermal sum, using base temperatures to obtain the daily thermal sum, for the Redenção cultivar (female parent), wild accessions (male parents), and respective interspecific hybrids of tomato (Solanum lycopersicum) on the transplanting dates 12/22/2015, 2/12/2016, and 4/6/2016. 
$(2 / 12 / 2016)$ to $7.5^{\circ} \mathrm{C}(4 / 6 / 2016)$, respectively (Figure $2)$. These values showed that the $F_{1}$ hybrids inherited characteristics related to Tbase for nodal emission from their respective male parents, PI-134417 and PI-127826. In contrast, higher Tbase values were observed for the other genotypes, ranging from 11 to $15^{\circ} \mathrm{C}$ (Figure 2).

Since Tbase for node emission varied little between transplanting dates, Tbase values for thermal sum and plastochron estimates were defined as the arithmetic mean of the three transplanting dates. These values were the following: $14.2^{\circ} \mathrm{C}$ for 'Redenção', $13.8^{\circ} \mathrm{C}$ for AF $26970,13.5^{\circ} \mathrm{C}$ for LA-1401, $12.2^{\circ} \mathrm{C}$ for AF 19684 , $5.2^{\circ} \mathrm{C}$ for PI-127826, $4.5^{\circ} \mathrm{C}$ for PI-134417, $14.8^{\circ} \mathrm{C}$ for LA-716, $13.0^{\circ} \mathrm{C}$ for 'Redenção' x AF $26970,11.8^{\circ} \mathrm{C}$ for 'Redenção' x LA-1401, $11.8^{\circ} \mathrm{C}$ for 'Redenção' x AF $19684,6.3^{\circ} \mathrm{C}$ for 'Redenção' x PI-127826, $6.4^{\circ} \mathrm{C}$ for 'Redenção' x PI-134417, and $14.8^{\circ} \mathrm{C}$ for 'Redenção' x LA-716.

The average Tbase of the Redenção cultivar, i.e., $14.2^{\circ} \mathrm{C}$ (Figure 2), was $4.2^{\circ} \mathrm{C}$ higher than that of $S$. lycopersicum tomatoes. It should be noted that 'Redenção' is a cultivar with a specific growth habit, with characteristics for industrial processing, recommended for cultivation in the lower-middle region of the São Francisco basin (Ferraz et al., 2003). The climatic conditions of the area where the breeding selection cycles were carried out to obtain the Redenção cultivar may have contributed to Tbase above $10^{\circ} \mathrm{C}$, which was the value used to calculate the thermal sum, as in Pivetta et al. (2007).

The estimated Tbase for node emission is indicative of the thermal energy required for plant development to begin (Sinclair et al., 2004; Martins et al., 2007). The obtained results show that the PI-127826 and PI-134417 accessions and their interspecific $F_{1}$ hybrids required lower Tbase for node emission. The descendants of the varieties of $S$. habrochaites, $S$. hirsutum, and $S$. glabratum are an alternative for breeding programs to obtain strains able to develop vegetatively with less thermal energy availability.

The plastochron estimated for the main stem only differed between transplanting dates for the genitor $S$. pennellii accession LA-716, showing 24.4, 31.5, and $30.0^{\circ} \mathrm{C}$ day per node, respectively, for $12 / 22 / 2015$, $2 / 12 / 2016$, and $4 / 6 / 2016$ (Table 1). The fact that the other genotypes showed similar plastochron values for the main stem is considered an advantage, since it makes the model more stable, broadly applicable, and easy to use, as also verified by Lucas et al. (2012) in 'Crimson Sweet' watermelon, at distinct cultivation dates and in three crop years.

The highest plastochron values for the main stem were observed in the LA-1401, AF 19684, and LA-

Table 1. Plastochron of the main stem for the Redenção cultivar (female parent), wild accessions (male parents), and respective interspecific hybrids of tomato (Solanum lycopersicum) on the transplanting dates 12/22/2015, 2/12/2016, and $4 / 6 / 2016^{(1)}$.

\begin{tabular}{|c|c|c|c|c|}
\hline \multirow[t]{2}{*}{ Genotype } & \multicolumn{3}{|c|}{ Plastochron $\left({ }^{\circ} \mathrm{C}\right.$ day per node $)$} & \multirow[t]{2}{*}{ Average } \\
\hline & $12 / 22 / 2015$ & $2 / 12 / 2016$ & $4 / 6 / 2016$ & \\
\hline 'Redenção' & $17.8 \mathrm{Ab}$ & $18.2 \mathrm{Ac}$ & 18.1Ad & $18.0 \mathrm{c}$ \\
\hline AF 26970 & $18.1 \mathrm{Ab}$ & 18.7Ac & 19.3Ac & $18.7 \mathrm{c}$ \\
\hline LA-1401 & $23.8 \mathrm{Aa}$ & $24.2 \mathrm{Ab}$ & $25.7 \mathrm{Ab}$ & $24.6 b$ \\
\hline AF 19684 & $25.5 \mathrm{Aa}$ & $25.5 \mathrm{Ab}$ & $26.2 \mathrm{Ab}$ & $25.7 b$ \\
\hline PI-127826 & $16.0 \mathrm{Ac}$ & $17.5 \mathrm{Ad}$ & 18.2Ad & $17.2 \mathrm{~d}$ \\
\hline PI-134417 & $16.5 \mathrm{Ac}$ & $18.5 \mathrm{Ac}$ & 18.7Ad & $17.9 \mathrm{~d}$ \\
\hline LA-716 & $24.4 \mathrm{Ba}$ & $31.5 \mathrm{Aa}$ & $30.0 \mathrm{Aa}$ & $28.6 \mathrm{a}$ \\
\hline 'Redenção' x AF 26970 & $18.5 \mathrm{Ab}$ & $19.5 \mathrm{Ac}$ & $20.3 \mathrm{Ac}$ & $19.4 \mathrm{c}$ \\
\hline 'Redenção' x LA-1401 & $17.8 \mathrm{Ab}$ & 19.1Ac & $20.1 \mathrm{Ac}$ & $19.0 \mathrm{c}$ \\
\hline 'Redenção' x AF 19684 & $18.1 \mathrm{Ab}$ & 19.1Ac & $20.3 \mathrm{Ac}$ & $19.2 \mathrm{c}$ \\
\hline 'Redenção' x PI-127826 & 15.7Ac & 16.3Ad & 17.9Ad & $16.6 \mathrm{e}$ \\
\hline 'Redenção' x PI-134417 & $15.1 \mathrm{Ac}$ & 16.2Ad & 16.9Ad & $16.1 \mathrm{e}$ \\
\hline 'Redenção' x LA-716 & $18.4 \mathrm{Ab}$ & $19.5 \mathrm{Ac}$ & $20.0 \mathrm{Ac}$ & $19.3 \mathrm{c}$ \\
\hline Average & $18.81 \mathrm{C}$ & $20.30 \mathrm{~B}$ & $20.91 \mathrm{~A}$ & - \\
\hline
\end{tabular}

${ }^{(1)}$ Means followed by equal letters, uppercase in lines and lowercase in columns, do not differ by Scott-Knott's test, at 5\% probability. 
716 wild accessions on $12 / 22 / 2015$; and in LA-716 on 2/12/2016 and 4/6/2016 (Table 1). These results show that the accessions required a greater accumulation of thermal energy to emit a node for the same air temperature on the different transplanting dates.

In relation to the first three lateral stems, the lowest plastochron values for the first two lateral stems were observed for the Redenção cultivar and the LA-1401 and PI-134417 accessions, as well as for the 'Redenção' x AF 26970 and 'Redenção' x LA-716 hybrids. The lowest values for the third lateral stem were observed for 'Redenção' x LA-716 (Table 2). In the third lateral stem, there was a greater interaction between genotypes and transplanting dates than in the main stem and the other lateral stems (Tables 1 and 2).

In the three transplanting dates, both on the main stem and on the lateral stems, lower plastochron values were found for the 'Redenção' x LA-716 interspecific hybrid, when compared with the LA716 male parent (Tables 1 and 2). This result makes it possible to infer that the 'Redenção' x LA-716 hybrid required a lower aTS for the appearance of nodes in the main and lateral stems than its wild parent. A similar behavior was also verified for the 'Redenção' x LA-1401 and 'Redenção' x AF 19684 hybrids on the main stem, 'Redenção' x AF 26970 on the first lateral stem, and 'Redenção' x PI-127826 on the third lateral stem, which presented lower plastochron values than the male parents. These results are possibly related to the heterotic effect due to the crosses of contrasting tomato genotypes (Figueiredo et al., 2017). In the present study, the interspecific crosses reduced the plastochron values obtained for the hybrid, compared with the average of the parents, showing a value close to that of the Redenção cultivar.

The accession $S$. galapagense LA-1401 was the only genotype with a lower plastochron value in the lateral stems than in the main stem in the three transplanting dates; the other genotypes showed a lower plastochron value on the main stem than on the lateral ones (Tables 1 and 2). For the Redenção cultivar, the AF 19684 and LA-716 accessions, and the 'Redenção' $\mathrm{x}$ AF 26970, 'Redenção' x LA-1401, 'Redenção' x AF 19684, 'Redenção' x PI-127826, and 'Redenção' x PI-134417 hybrids, lower plastochron values were observed in the first two lateral stems (Table 2).

For S. habrochaites var. glabratum accession PI134417 (Figure 2), besides the lower average Tbase $\left(4.5^{\circ} \mathrm{C}\right)$, low plastochron values were found for the main and lateral stems (Tables 1 and 2). Therefore, it can be inferred that this accession, as well as $S$. habrochaites var. hirsutum accession PI-127826, if developed with lower thermal availability, shows a greater efficiency in node emission as a function of air temperature.

Table 2. Plastochron $\left({ }^{\circ} \mathrm{C}\right.$ day per node) of the three first-order lateral stems for the Redenção cultivar (female parent), of wild accessions (male parents), and respective interspecific hybrids of tomato (Solanum lycopersicum) on the transplanting dates $12 / 2 / 2015,2 / 12 / 2016$, and 4/6/2016 (1).

\begin{tabular}{|c|c|c|c|c|c|c|c|c|c|c|c|c|}
\hline \multirow[t]{2}{*}{ Genotype } & \multicolumn{3}{|c|}{ LS1 } & \multirow[t]{2}{*}{ Average } & \multicolumn{3}{|c|}{ LS2 } & \multirow[t]{2}{*}{ Average } & \multicolumn{3}{|c|}{ LS3 } & \multirow[t]{2}{*}{ Average } \\
\hline & $12 / 22 / 2015$ & $2 / 12 / 2016$ & $4 / 6 / 2016$ & & $12 / 22 / 2015$ & $2 / 12 / 2016$ & $4 / 6 / 2016$ & & $12 / 22 / 2015$ & $2 / 12 / 2016$ & $4 / 6 / 2016$ & \\
\hline 'Redenção' & $18.1 \mathrm{Ac}$ & $19.0 \mathrm{Ac}$ & $20.0 \mathrm{Ac}$ & $19.0 \mathrm{~d}$ & $20.4 \mathrm{Ad}$ & $19.5 \mathrm{Ac}$ & $21.7 \mathrm{Ac}$ & $20.5 \mathrm{c}$ & $32.0 \mathrm{Ac}$ & $31.5 \mathrm{Ad}$ & $33.2 \mathrm{Ad}$ & $32.0 \mathrm{e}$ \\
\hline AF 26970 & $28.2 \mathrm{Ab}$ & $26.9 \mathrm{Ab}$ & $29.3 \mathrm{Ab}$ & $28.1 \mathrm{~b}$ & $27.5 \mathrm{Ac}$ & $29.3 \mathrm{Ab}$ & $31.1 \mathrm{Ab}$ & $29.3 b$ & $29.7 \mathrm{Ac}$ & $30.3 \mathrm{Ad}$ & $32.1 \mathrm{Ad}$ & $30.7 \mathrm{e}$ \\
\hline LA-1401 & $19.9 \mathrm{Ac}$ & $20.1 \mathrm{Ac}$ & $21.4 \mathrm{Ac}$ & $20.5 \mathrm{~d}$ & $20.0 \mathrm{Ad}$ & $21.1 \mathrm{Ac}$ & $22.4 \mathrm{Ac}$ & $21.2 \mathrm{c}$ & $20.0 \mathrm{Ad}$ & 19.1Ae & $22.4 \mathrm{Ae}$ & $20.5 f$ \\
\hline AF 19684 & $27.1 \mathrm{Ab}$ & $28.0 \mathrm{Ab}$ & $29.2 \mathrm{Ab}$ & $28.1 \mathrm{~b}$ & $25.3 \mathrm{Ac}$ & $28.0 \mathrm{Ab}$ & $25.7 \mathrm{Ac}$ & $26.3 b$ & $31.3 \mathrm{Ac}$ & $30.6 \mathrm{Ad}$ & 33.0Ad & $31.6 \mathrm{e}$ \\
\hline PI-127826 & $25.0 \mathrm{Cb}$ & $33.5 \mathrm{Ba}$ & $41.2 \mathrm{Aa}$ & $33.2 \mathrm{a}$ & $40.0 \mathrm{Ab}$ & 40.9Aa & 43.0Aa & $41.3 \mathrm{a}$ & $59.8 \mathrm{Ba}$ & $57.2 \mathrm{Bb}$ & 68.0Aa & $61.7 \mathrm{~b}$ \\
\hline PI-134417 & $18.4 \mathrm{Ac}$ & $18.9 \mathrm{Ac}$ & $19.5 \mathrm{Ac}$ & $18.9 \mathrm{~d}$ & $20.2 \mathrm{Ad}$ & $20.0 \mathrm{Ac}$ & 21.9Ac & $20.7 \mathrm{c}$ & 20.9Ad & $19.8 \mathrm{Ae}$ & 21.1Ae & $20.6 f$ \\
\hline LA-716 & $32.0 \mathrm{Aa}$ & $33.5 \mathrm{Aa}$ & $30.9 \mathrm{Ab}$ & $32.1 \mathrm{a}$ & $49.0 \mathrm{Aa}$ & $29.3 \mathrm{Bb}$ & $48.2 \mathrm{Aa}$ & $42.2 \mathrm{a}$ & $61.0 \mathrm{Ba}$ & $85.2 \mathrm{Aa}$ & $58.7 \mathrm{Bb}$ & $68.3 \mathrm{a}$ \\
\hline 'Redenção' x AF26970 & $21.5 \mathrm{Ac}$ & $22.5 \mathrm{Ac}$ & $23.3 \mathrm{Ac}$ & $22.4 \mathrm{c}$ & 21.7Ad & 20.9Ac & $21.0 \mathrm{Ac}$ & $21.2 \mathrm{c}$ & $30.7 \mathrm{Bc}$ & $30.0 \mathrm{Bd}$ & $44.6 \mathrm{Ac}$ & $35.1 \mathrm{~d}$ \\
\hline 'Redenção' x LA-1401 & $27.8 \mathrm{Ab}$ & $28.1 \mathrm{Ab}$ & $29.5 \mathrm{Ab}$ & $28.5 b$ & $28.2 \mathrm{Ac}$ & $29.0 \mathrm{Ab}$ & $27.3 \mathrm{Ac}$ & $28.2 b$ & $39.8 \mathrm{Bb}$ & $41.1 \mathrm{Bc}$ & $55.0 \mathrm{Ab}$ & $45.3 \mathrm{c}$ \\
\hline 'Redenção' x AF 19684 & $27.7 \mathrm{Ab}$ & $27.1 \mathrm{Ab}$ & $28.9 \mathrm{Ab}$ & $27.9 b$ & $25.7 \mathrm{Ac}$ & $27.1 \mathrm{Ab}$ & $26.3 \mathrm{Ac}$ & $26.4 b$ & $40.1 \mathrm{Ab}$ & $40.5 \mathrm{Ac}$ & $43.9 \mathrm{Ac}$ & $41.5 \mathrm{c}$ \\
\hline 'Redenção' x PI-127826 & 31.9Aa & $33.9 \mathrm{Aa}$ & $30.6 \mathrm{Ab}$ & $32.1 \mathrm{a}$ & $37.0 \mathrm{Bb}$ & $33.2 \mathrm{Bb}$ & $46.8 \mathrm{Aa}$ & $39.0 \mathrm{a}$ & $44.0 \mathrm{Ab}$ & $43.2 \mathrm{Ac}$ & $42.0 \mathrm{Ac}$ & $43.1 \mathrm{c}$ \\
\hline 'Redenção' x PI-134417 & $32.7 \mathrm{Aa}$ & $33.4 \mathrm{Aa}$ & $33.1 \mathrm{Ab}$ & $33.1 \mathrm{a}$ & $22.3 \mathrm{Bd}$ & $32.0 \mathrm{Ab}$ & $34.6 \mathrm{Ab}$ & $29.6 b$ & $39.5 \mathrm{Ab}$ & 43.0Ac & 42.7Ac & $41.7 \mathrm{c}$ \\
\hline 'Redenção' x LA-716 & $19.9 \mathrm{Ac}$ & $21.9 \mathrm{Ac}$ & $22.1 \mathrm{Ac}$ & $21.3 \mathrm{c}$ & 21.9Ad & $22.5 \mathrm{Ac}$ & $25.2 \mathrm{Ac}$ & $23.2 \mathrm{c}$ & $30.4 \mathrm{Ac}$ & $21.7 \mathrm{Ae}$ & $22.9 \mathrm{Ae}$ & $25.0 \mathrm{f}$ \\
\hline Average & $25.4 \mathrm{C}$ & $26.7 \mathrm{~B}$ & $27.6 \mathrm{~A}$ & - & $27.6 \mathrm{~B}$ & $27.1 \mathrm{~B}$ & $30.4 \mathrm{~A}$ & - & $36.7 \mathrm{~B}$ & $37.9 \mathrm{~B}$ & $39.9 \mathrm{~A}$ & - \\
\hline
\end{tabular}

${ }^{(1)}$ Means followed by equal letters, uppercase in lines and lowercase in columns, do not differ by Scott-Knott's test, at 5\% probability. LS1, first lateral stem; LS2, second lateral stem; and LS3, third lateral stem. 


\section{Conclusions}

1. Wild species and interspecific hybrids of tomato (Solanum lycopersicum) show a great variation in base temperature for node emission and plastochron determination.

2. The wild species of tomato $S$. habrochaites var. hirsutum accession PI-127826 and S. habrochaites var. glabratum accession PI-134417, as well as their hybrids with $S$. lycopersicum, present the lowest values of base temperature and plastochron for the main stem, while the other wild species and interspecific hybrids have a base temperature close to that of the cultivated tomato.

\section{Acknowledgments}

To Coordenação de Aperfeiçoamento de Pessoal de Nível Superior (Capes), for the scholarship granted.

\section{References}

ARNOLD, C.Y. Maximum-minimum temperature as a basis for computing heat units. Americam Society for Horticulture Science, v.76, p.682-692, 1960.

BRÜGGEMANN, W.; LINGER, P. Long-term chilling of young tomato plants under low light. IV. Differential responses of chlorophyll fluorescence quenching coefficients in Lycopersicon species of different chilling sensitivity. Plant and Cell Physiology, v.35, p.585- 591, 1994. DOI: 10.1093/oxfordjournals.pcp.a078633.

CALLEJAS, I.J.A.; NEVES, G.A.R.; TAVARES, A. da S.; MOURA, I.B. de; LIMA, E.A. de. Determinação das temperaturas cardinais da manga cultivar Roxa através de simulação computacional utilizando um modelo não linear. Ambiência, v.10, p.97-110, 2014. DOI: 10.5935/ambiencia.2014.01.08.

EASLON, H.M.; ASENSIO, J.S.; ST CLAIR, D.A.; BLOOM, A.J. Chilling-induced water stress: variation in shoot turgor maintenance among wild tomato species from diverse habitats. American Journal of Botany, v.100, p.1991-1999, 2013. DOI: 10.3732/ajb.1200508.

ERPEN, L.; STRECK, N.A.; UHLMANN, L.O.; LANGNER, J.A.; WINCK, J.E.M.; GABRIEL, L.F. Estimativa das temperaturas cardinais e modelagem do desenvolvimento vegetativo em batatadoce. Revista Brasileira de Engenharia Agrícola e Ambiental, v.17, p.1230-1238, 2013. DOI: 10.1590/S1415-43662013001100015.

FERRAZ, E.; RESENDE, L.V.; LIMA, G.S.A.; SILVA, M.C.L.; FRANÇA, J.G.E. de; SILVA, D.J. da. Redenção: nova cultivar de tomate para a indústria resistente a geminivírus e tospovírus. Horticultura Brasileira, v.21, p.578-580, 2003. DOI: 10.1590/ S0102-05362003000300033.

FIGUEIREDO, A.S.T.; RESENDE, J.T.V. de; SCHWARZ, K.; MARODIN, J.C.; GALVAO, A.G.; RESENDE, N.C.V. Genetic divergence among processing tomato hybrids and formation of new segregating populations. Ciência e Agrotecnologia, v.41, p.279-287, 2017. DOI: 10.1590/1413-70542017413033016.

HELDWEIN, A.B.; STRECK, N.A.; STURZA, V.S.; LOOSE, L.H.; ZANON, A.J.; TOEBE, M.; SOUZA, A.T. de; PETERS, M.B.; KARLEC, F. Plastocrono e rendimento de feijão-devagem cultivado sob ambiente protegido e no ambiente externo em semeadura tardia no outono. Ciência Rural, v.40, p.768-773, 2010. DOI: $10.1590 / \mathrm{S} 0103-84782010005000045$.

LIU, B.; HEINS, R.D. Photothermal ratio affects plant quality in 'Freedom' Poinsettia. Journal of the American Society for Horticultural Science, v.127, p.20-26, 2002.

LUCAS, D.D.P.; STRECK, N.A.; BORTOLUZZI, M.P.; TRENTIN, R.; MALDANER, I.C. Temperatura base para emissão de nós e plastocrono de plantas de melancia. Revista Ciência Agronômica, v.43, p.288-292, 2012. DOI: 10.1590/ S1806-66902012000200011.

MARTINS, F.B.; SILVA, J.C. da; STRECK, N.A. Estimativa da temperatura-base para emissão de folhas e do filocrono em duas espécies de eucalipto na fase de muda. Revista Árvore, v.31, p.373-381, 2007. DOI: 10.1590/S0100-67622007000300002.

MÜLLER, L.; MANFRON, P.A.; MEDEIROS, S.L.P.; STRECK, N.A.; MITTELMMAN, A.; DOURADO NETO, D.; BANDEIRA, A.H.; MORAIS, K.P. Temperatura base inferior e estacionalidade de produção de genótipos diplóides e tetraplóides de azevém. Ciência Rural, v.39, p.1343-1348, 2009. DOI: 10.1590/S010384782009005000098 .

OTTO, M.S.G.; VERGANI, A.R.; GONÇALVES, A.N.; VRECHI, A.; SILVA, S.R.; STAPE, J.L. Fotossíntese, condutância estomática e produtividade de clones de Eucalyptus sob diferentes condições edafoclimáticas. Revista Árvore, v.36, p.431-439, 2013. DOI: 10.1590/S0100-67622013000300006.

PATTERSON, B.D.; PAUL, R.; SMILLIE, R.M. Chilling resistance in Lycopersicon hirsutum Humb. \& Bonpl., a wild tomato with a wide altitudinal distribution. Australian Journal of Plant Physiology, v.5, p.609-617, 1978. DOI: 10.1071/PP9780609.

PERALTA, I.E.; SPOONER, D.M.; KNAPP, S. Taxonomy of wild tomatoes and their relatives (Solanum sect. Lycopersicoides, sect. Juglandifolia, sect. Lycopersicon; Solanaceae). Systematic Botany Monographs, v.8, p.1-186, 2008.

PEREIRA, L.C.; CAMPELO JÚNIOR, J.H.; FERRONATO, A. Comparação de métodos para estimativa do plastocrono em algodoeiro em condições tropicais. Pesquisa Agropecuária Tropical, v.40, p.213-220, 2010. DOI: 10.5216/pat.v40i2.6716.

PIVETTA, C.R.; TAZZO, I.F.; MAASS, G.F.; STRECK, N.A.; HELDWEIN, A.B. Emissão e expansão foliar em três genótipos de tomateiro (Lycopersicon esculentum Mill.). Ciência Rural, v.37, p.1274-1280, 2007. DOI: 10.1590/S0103-84782007000500009.

SANTOS, H.G. dos; JACOMINE, P.K.T.; ANJOS, L.H.C. dos; OLIVEIRA, V.A. de; LUMBRERAS, J.F.; COELHO, M.R.; ALMEIDA, J.A. de; CUNHA, T.J.F.; OLIVEIRA, J.B. de. Sistema brasileiro de classificação de solos. 3.ed. rev. e ampl. Brasília, DF: Embrapa, 2013. 353p.

SILVA, F. de A.S. e; AZEVEDO, C.A.V. de. The Assistat Software Version 7.7 and its use in the analysis of experimental data. 
African Journal of Agricultural Research, v.11, p.3733-3740, 2016. DOI: 10.5897/AJAR2016.11522.

SINCLAIR, T.R.; GILBERT, R.A.; PERDOMO, R.E.; SHINE JR., J.M.; POWELL, G.; MONTES, G. Sugarcane leaf area development under field conditions in Florida, USA. Field Crops Research, v.88, p.171-178, 2004. DOI: 10.1016/j.fcr.2003.12.005.

SOUZA, L.C. de; COSTA, A.V.A. da; MOREIRA, W.K.O.; SILVA, E.G. da; SOUZA, A.C. de; SILVA, R.T.L. da. Métodos de soma térmica na determinação de plastocrono de Helianthus annuus L. cultivado em ambiente protegido em Capitão Poço-PA. Nucleus, v.13, p.143-152, 2016. DOI: 10.3738/1982.2278.1640.

STRECK, N.A.; BELLÉ, R.A.; ROCHA, E.K.; SCHUH, M. Estimating leaf appearance and phyllochron in safflower (Carthamus tinctorius L.). Ciência Rural, v.35, p.1448-1450, 2005. DOI: $10.1590 / \mathrm{S} 0103-84782005000600036$.

STRECK, N.A.; PAULA, G.M. de; CAMERA, C.; MENEZES, N.L. de; LAGO, I. Estimativa do plastocrono em cultivares de soja. Bragantia, v.67, p.67-73, 2008. DOI: 10.1590/S000687052008000100008 .

TOEBE, M.; LOPES, S.J.; STORCK, L.; SILVEIRA, T.R. da; MILANI, M.; CASAROTTO, G. Estimativa de plastocrono em crambe. Ciência Rural, v.40, p.793-799, 2010. DOI: 10.1590/ S0103-847820050006000361.

VENEMA, J.H.; BOUKELIEN, E.D.; BAX, J.M.; HASSELT, P.R. van; ELZENGA, J.T.M. Grafting tomato (Solanum lycopersicum) onto the rootstock of a high-altitude accession of Solanum habrochaites improves suboptimal-temperature tolerance. Environmental and Experimental Botany, v.63, p.359-367, 2008. DOI: 10.1016/j.envexpbot.2007.12.015.

VENEMA, J.H.; VILLERIUS, L.; VAN HASSELT, P.R. Effect of acclimation to suboptimal temperature on chilling-induced photodamage: comparison between a domestic and a high-altitude wild Lycopersicon species. Plant Science, v.152, p.153-163, 2000. DOI: 10.1016/S0168-9452(99)00228-9.

WREGE, M.S.; STEINMETZ, S.; REISSER JÚNIOR, C.; ALMEIDA, I.R. de. Atlas climático da Região Sul do Brasil: Estados do Paraná, Santa Catarina e Rio Grande do Sul. Pelotas: Embrapa Clima Temperado; Colombo: Embrapa Florestas, 2011. $336 \mathrm{p}$.

ZEIST, A.R.; ALBERTO, C.M.; TOMAZETTI, T.C.; ROSSAROLlA, M.D.; GIACOBBO, C.L.; WELTER, L.J. Plastochron estimate in grapevine 'Marselan' and 'Tannat' cultivars. Científica, v.44, p.471-476, 2016. DOI: 10.15361/1984-5529.2016v4 4n4p471-476.

ZEIST, A.R.; TOMAZETTI, T.C.; ROSSAROLLA, M.D.; ALBERTO, C.M.; GIACOBBO, C.L.; WELTER, L.J. Plastochron index of 'Cabernet Sauvignon' and 'Chardonnay' grapevines in Fronteira Oeste, in the state of Rio Grande do Sul, Brazil. Pesquisa Agropecuária Brasileira, v.52, p.244-251, 2017. DOI: 10.1590/s0100-204x2017000400004.

Received on March 20, 2017 and accepted on July 8, 2017

Pesq. agropec. bras., Brasília, v.53, n.3, p.307-315, Mar. 2018 DOI: 10.1590/S0100-204X2018000300005 